\title{
Gambaran Sumber Terjadinya Infeksi pada Penderita Sepsis dan Syok Septik di ICU RSUP Prof. Dr. R. D. Kandou Manado Periode Agustus 2016 sampai dengan September 2017
}

\author{
${ }^{1}$ Juniarty J. P. Nainggolan \\ ${ }^{2}$ Lucky T. Kumaat \\ ${ }^{2}$ Mordekhai L. Laihad
}

\author{
${ }^{1}$ Program Studi Pendidikan Dokter Fakultas Kedokteran Universitas Sam Ratulangi Manado \\ ${ }^{2}$ Bagian Anestesiologi dan Terapi Intensif Universitas Sam Ratulangi Manado \\ Email: juninainggolan@gmail.com
}

\begin{abstract}
Sepsis is defined as life-threatening organ dysfunction caused by dysregulation of host response to infection meanwhile septic shock is defined as a subset of sepsis with severe circulatory and cellular metabolism abnormalities. The incidence of sepsis has been increasing for the past three decades, and becomes the most frequent cause of death among other common diseases in the Western countries such as myocardial infarction, stroke, and trauma. This study was aimed to find out the description of infection in sepsis and septic shock patients in Intensive Care Unit (ICU) of Prof. Dr. R. D. Kandou Hospital Manado. This was a rectrospective descriptrive study. Data were obtained from the medical record of sepsis patients in the period of August 2016 until September 2017. Samples were determined by using purposive sampling method. The results showed that the source of sepsis infection and septic shock was mostly caused by pneumonia as many as 50 samples, as follows: 21 patiens (31.3\%) with HAP, 11 patients with CAP (16.4\%), and 18 patients with VAP (26.9\%). Other sources were 8 patients $(11,9 \%)$ with urosepsis, 3 patients $(4.5 \%)$ with cholangitis, 2 patients (3.0\%) with abscess, 1 patient (1.5\%) with diabetic foot, 1 patient (1.5\%) with osteomyelitis , 1 patient with decubitus ulcer, and 1 patient (1.5\%) with intraabdominal infection. Conclusion: The most common source of sepsis infection and septic shock was pneumonia infection; HAP was the leading one.
\end{abstract}

Keywords: sources of infection, sepsis, shock septic

\begin{abstract}
Abstrak: Sepsis adalah ancaman kehidupan akibat disfungsi organ yang disebabkan oleh disregulasi respon terhadap infeksi. Syok septik adalah bagian dari sepsis dengan kelainan sirkulasi, seluler, atau metabolik yang cukup parah. Kejadian sepsis terus meningkat selama tiga dekade terakhir, dan menjadi penyebab kematian tertinggi dibandingkan penyakitpenyakit umum lainnya di negara Barat seperti miokard infark, stroke, dan trauma. Penelitian ini bertujuan untuk mengetahui gambaran sumber terjadinya infeksi pada penderita sepsis dan syok septik di Intensive Care Unit (ICU) RSUP Prof. Dr. R. D. Kandou Manado. Jenis penelitian ialah deskriptif retrospektif menggunakan data rekam medik pasien sepsis di RSUP Prof. Dr. R. D. Kandou Manado periode Agustus 2016 - September 2017. Besar sampel ditentukan dengan metode purposive sampling. Dari hasil penelitian didapatkan bahwa sumber terjadinya infeksi sepsis dan syok septik paling banyak disebabkan pneumonia (50 orang) yaitu HAP 21 pasien $(31,3 \%)$, CAP 11 pasien $(16,4 \%)$, VAP 18 pasien $(26,9 \%)$. Sumber lainnya ialah urosepsis 8 pasien $(11,9 \%)$, kolangitis 3 pasien $(4,5 \%)$, abses 2 pasien $(3,0 \%)$, kaki diabetes 1 pasien $(1,5 \%)$, osteomielitis 1 pasien $(1,5 \%)$, ulkus dekubitus 1pasien $(1,5 \%)$, dan infeksi intraabdomen 1 pasien (1,5\%). Simpulan: Sumber terjadinya infeksi sepsis dan syok septik terutama disebabkan pneumonia, yang terbanyak ialah HAP.
\end{abstract}

Kata kunci: sumber infeksi, sepsis, syok septik 
Menurut konsensus internasional ke 3 pada tahun 2016, sepsis adalah ancaman kehidupan disfungsi organ yang disebabkan oleh disregulasi respon terhadap infeksi. Syok septik adalah bagian dari sepsis dimana terdapat kelainan sirkulasi, seluler atau metabolik yang cukup parah yang mening-katkan mortalitas. ${ }^{1}$ Dari jenis-jenis bakteri, penyebab tersering terjadinya sepsis ialah bakteri Gram negatif sebanyak 20-35\%. Namun dari beberapa dekade terakhir dilaporkan peningkatan bakteri Gram positif pada kultur darah penderita sepsis. $^{2}$

Kejadian sepsis terus meningkat selama tiga dekade terakhir, dan hampir $15 \%$ dari pasien yang dirawat di ruang intensif didiagnosis dengan severe sepsis; dua pertiga dari pasien-pasien tersebut mengalami syok septik. Sepsis menjadi penyebab kematian tertinggi dibandingkan dengan penyakit-penyakit umum lainnya di negara-negara Barat seperti miokard infark, stroke dan trauma. ${ }^{3}$

Pada penelitian yang dilakukan di Canada tahun 1996 sampai dengan 2007 didapatkan sumber infeksi sepsis dan syok sepsis sebagai berikut: infeksi pernapasan $41,2 \%$, infeksi intra-abdominal $23,1 \%$, infeksi saluran kemih $12,9 \%$, infeksi jaringan lunak $9,5 \%$, infeksi pembuluh darah primer $5,2 \%$, infeksi akibat penggunaan kateter $4,2 \%$, infeksi akibat pembedahan $1,6 \%$, infeksi sistem saraf pusat $1,4 \%$, dan lainnya $1 \% .^{4}$

Pada penelitian yang dilakukan di ICU RSCM Jakarta periode Oktober 2011November 2012 didapatkan sumber infeksi sepsis dan syok septik dari saluran napas $67,2 \%$, intraabdomen/saluran cerna $32,7 \%$, kulit/ jaringan lunak $15,4 \%$, saluran kemih $8,6 \%$, intrakranial $4,1 \%$, dan bakterimia $8,2 \% .^{5}$

Angka mortalitias sepsis sangat tinggi yang didukung oleh berbagai macam penelitian. Dari penelitian pada kurun waktu Desember 2014 - November 2015 di RSUP Prof. Dr. R. D Kandou Manado didapatkan bahwa angka mortalitas pasien sepsis jauh lebih tinggi dari angka keselamatan pasien sepsis di ICU. Dari 35 pasien, 23 orang $(65,7 \%)$ meninggal dunia sedangkan 12 orang $(34,3 \%)$ berhasil keluar dari ruang perawatan ICU dengan kondisi yang semakin membaik. Sumber terbanyak ialah pneumonia 25 orang $(71,4 \%)$, urosepsis 3 orang $(8,5 \%)$, laparotomi 3 orang $(8,5 \%)$, kolangitis 1 orang $(2,8 \%)$, ARDS 1 orang $(2,8 \%)$, ulkus dekubitus 1 orang $(2,8 \%)$, dan ensefalopati tifoid 1 orang $(2,8 \%){ }^{6}$

Penelitian ini bertujuan untuk mengetahui gambaran sumber terjadinya infeksi pada penderita sepsis dan syok septik di Intensive Care Unit (ICU) RSUP Prof. Dr. R.D Kandou Manado periode Agustus 2016- September 2017.

\section{METODE PENELITIAN}

Jenis penelitian ini ialah deskriptif retrospektif. Populasi ialah semua penderita sepsis di RSUP Prof. Dr. R.D. Kandou Manado periode Agustus 2016- September 2017. Sampel ialah semua penderita sepsis dan syok septik yang dirawat di ruang ICU RSUP Prof. Dr. R. D. Kandou Manado yang memenuhi kriteria inklusi. Data yang digunakan ialah data rekam medik pasien ICU periode Agustus 2016-September 2017. Besar sampel ditentukan dengan metode non probability sampling yaitu purposive sampling.

\section{HASIL PENELITIAN}

Berdasarkan data yang diperoleh jumlah pasien yang memenuhi kriteria inklusi ialah sebanyak 67 orang yang terdiri dari pasien sepsis dan syok septik.

Sumber terjadinya infeksi pada penderita sepsis dan syok septik yang dijadikan subjek penelitian ialah pada penyakit pneumonia sebanyak 50 orang, dimana tedapat HAP 21 orang $(31,3 \%)$, CAP sebanyak11 orang $(16,4 \%)$, dan VAP 18 orang $(26,9 \%)$. Selanjutnya urosepsis 8 orang $(11,9 \%)$, cholangitis 3 orang $(4,5 \%)$, abses 2 orang $(3,0 \%)$, kaki diabetes 1 orang $(1,5 \%)$, osteomilitis 1 orang $(1,5 \%)$, ulkus dekubitus 1 orang $(1,5 \%)$, dan infeksi intraabdomen 1 orang $(1,5 \%)$. 
Tabel 1. Distribusi frekuensi subjek penelitian sumber terjadinya infeksi

\begin{tabular}{lcc}
\hline \multicolumn{1}{c}{ Sumber } & $\begin{array}{c}\text { Frekuensi } \\
\text { (Orang) }\end{array}$ & \% \\
\hline HAP & 21 & 31,3 \\
CAP & 11 & 16,4 \\
VAP & 18 & 26,9 \\
Urosepsis & 8 & 11,9 \\
Cholangitis & 3 & 4,5 \\
Abses & 2 & 3,0 \\
Diabetic Foot & 1 & 1,5 \\
Osteomielitis & 1 & 1,5 \\
Ulkus dekubitus & 1 & 1,5 \\
Infeksi intraabdomen & 1 & 1,5 \\
Total & 67 & 100 \\
\hline
\end{tabular}

Tabel 2. Data demografi penyebaran sampel penelitian

\begin{tabular}{cc}
\hline Jenis kelamin n (\%) & $\mathbf{n}(\%)$ \\
Laki-laki & $30(44,8)$ \\
Perempuan & $37(55,2)$ \\
Usia (tahun) & \\
$15-29$ & $4(6)$ \\
$30-44$ & $8(12)$ \\
$45-59$ & $23(34,5)$ \\
$60-74$ & $22(33)$ \\
$75-90$ & $10(15)$ \\
Jenis & \\
Sepsis & $40(59,7)$ \\
Syok Septik & $27(40,3)$ \\
Angka mortalitas & \\
Meninggal & $52(77,6)$ \\
Pindah ruangan & $15(22,4)$ \\
Asal pasien & \\
Pasien dari lingkungan RSUP & $29(43,3)$ \\
Pasien rujukan & $38(56,7)$ \\
\hline
\end{tabular}

Tabel 2 menunjukan demografi penyebaran sampel penelitian. Jenis kelamin terbanyak ialah perempuan sebanyak 37 orang $(55,2 \%)$ sedangkan laki-laki sebanyak 30 orang $(44,8 \%)$. Usia tebanyak ialah kelompok usia 45-59 tahun sebanyak 23 orang (34,5\%), diikuti usia 60-74 tahun sebanyak 22 orang (33\%); yang paling sedikit didapatkan pada usia 15-29 tahun yaitu sebanyak 4 orang $(6 \%)$. Jenis terbanyak yaitu sepsis sebanyak 40 orang $(59,7 \%)$ dan syok septik sebanyak 27 orang (40,3\%). Angka kematian sepsis dan syok septik yaitu sebanyak 52 orang meninggal $(77,6 \%)$ dan sebanyak $15(22,4 \%)$ orang berhasil pindah ruangan atau keluar dari ICU. Frekuensi pasien sepsis dan syok septik di ICU RSUP Prof. Dr. R. D. Kandou terbanyak didapat dari hasil rujukan rumah sakit lain yaitu sebanyak 38 orang $(56,7 \%)$ dan dari lingkungan rumah sakit sendiri 29 orang $(43,3 \%)$.

\section{BAHASAN}

Didapatkan bahwa sepsis dan syok septik terbanyak besumber dari saluran napas yaitu pneumonia pada sebanyak 50 orang, yang terbagi atas human acquired pneumonia (HAP), community acquired pneumonia (CAP), dan ventilator acquired pneumonia (VAP). Data menunjukkan bahwa HAP memiliki peran terbanyak yaitu sebanyak 21 orang $(31,3 \%)$, diikuti oleh CAP 11 orang $(16,4 \%)$, dan VAP 18 orang $(26,9 \%)$. Hasil yang sejalan juga ditemukan pada penelitian yang dilakukan di ICU RSUP dr. Kariadi yaitu dari 126 pasien sepsis dan syok septik ditemukan sumber utama sepsis dan syok septik ialah pneumonia sebanyak $42 \%$. $^{7}$ Hal ini disebabkan kuman S.Pneumonia mudah masuk ke dalam tubuh melalui inhalasi atau aspirasi ke segmen paru-paru/lobus paruparu. ${ }^{8}$ Infeksi pneumonia dapat terjadi sebelum masuk rumah sakit, saat mendapatkan penanganan medis, atau saat menjalankan proses perawatan di ICU. ${ }^{9}$

Kejadian pneumonia nosokomial (HAP) dan VAP di ICU lebih banyak di jumpai dari semua infeksi dengan angka mortalitas dapat mencapai 33-50\%. ${ }^{10}$ Penyebab pneumonia nosokomial di ICU terjadi akibat tindakan invasif yang diberikan pada pasien berupa infus, intubasi, trakeostomi, dan pemasangan ventilator. $^{11}$

Data yang ditemukan dari catatan rekam medik ICU tidak mencantumkan hasil kultur terutama jenis kuman penyebab dan sensitivitas test terhadap antibiotik sesuai kuman. Sekitar $86 \%$ dari penyakit nosokomial pneumonia terinfeksi dari penggunaan ventilasi mekanik yaitu VAP. ${ }^{8}$ Infeksi nosokomial di ICU berhubungan 
dengan peningkatan angka kematian, angka kesakitan dan lama waktu perawatan, dengan angka kematian cukup tinggi yaitu $33-50 \%{ }^{10}$

Dari hasil penelitian di ICU RSUP Prof. Dr. R. D. Kandou Manado, sumber kedua sepsis dan syok septik ialah urosepsis $(11,9 \%)$. Hasil yang hampir sama didapat dari penelitian yang dilakukan di Jerman dimana urosepsis menyumbang 9$31 \%$ dari semua kasus sepsis dan syok septik dan memiliki angka kematian 20$40 \%$, tetapi lebih rendah dibandingkan dengan sepsis pada umumnya. ${ }^{12}$ Hal ini disebabkan mikrobakteria yang berasal dari saluran urogenital, dipengaruhi dengan penggunaan kateter urin dan bakteri dengan mudah masuk ke dalam peredaran darah karena pasien mengalami penurunan kekebalan tubuh. ${ }^{13}$

Data yang didapatkan dari pasien yang dirawat di ICU RSUP Prof. dr. R. D. Kandou Manado periode Agustus 2016 September 2017 memperliahatkan sumber infeksi sepsis dan syok septik akibat kolangitis sebanyak 3 orang $(4,5 \%)$, yang menunjukkan sedikit peningkatan dibandingkan penelitian yang dilakukan pada Desember 2014 - November 2015 di ICU RSUP Prof. Dr. R. D. Kandou Manado yaitu 1 orang saja.

Adanya hambatan dari aliran cairan empedu akan menimbulkan stasis cairan empedu, kolonisasi bakteri dan partumbuhan kuman yang berlebihan. Kumankuman ini berasal dari flora duodenum yang masuk melalui sfingter Oddi, dapat juga disebabkan penyebaran limfogen dari kandung empedu yang mengalami radang akut, penyebaran ke hati, atau melalui sirkulasi portal dari bakteri usus. Karena tekanan tinggi dari saluran empedu yang tersumbat, kuman akan kembali (refluks) ke dalam saluran limfe dan aliran darah dan mengakibatkan sepsis. ${ }^{14}$

Dari data yang didapatkan, sumber terjadinya sepsis dan syok septik juga berasal dari abses pada 2 orang $(3,0 \%)$, dan diikuti kaki diabetes 1 orang $(1,5 \%)$, osteomielitis 1 orang $(1,5 \%)$, dan ulkus dekubitus 1 orang $(1,5 \%)$. Pada penelitian yang dilakukan di RS Soetomo Surabaya didapatkan bahwa sumber infeksi sepsis dan syok septik yang berasal daari kulit, jaringan lunak, dan tulang sebanyak 3 orang $(10 \%){ }^{15}$

Pada hasil selanjutnya didapatkan bahwa sumber terjadinya infeksi sepsis dan syok sepsis bersumber dari infeksi intraabdomen yaitu pada 1 orang $(1,5 \%)$. Pada penelitian yang dilakukan di RS Soetomo Surabaya tahun 2011 didapatkan infeksi intraabdomen memegang peranan yang cukup tinggi yaitu sebanyak 9 orang $(30 \%){ }^{15}$

\section{SIMPULAN}

Dari hasil penelitian di ICU RSUP Prof. Dr. R. D. Kandou dapat disimpulkan bahwa sumber terjadinya infeksi sepsis dan syok septik terbanyak disebabkan pneumonia yang didominasi oleh HAP, disusul oleh CAP dan VAP. Sumber lainnya ialah urosepsis, kolangitis, abses, kaki diabetes, osteomielitis, dan ulkus dekubitus.

\section{SARAN}

Untuk institusi rekam medik agar dapat memaksimalkan proses penyimpanan data sehingga dapat mempermudah penelitian selanjutnya.

Untuk rumah sakit khususnya ICU sebaiknya dilakukan pemeriksaan kuman sehingga dapat diketahui etiologi kuman penyebab. Kelengkapan pengisian status pasien sangat diperlukan guna menunjang pendekatan yang lengkap, akurat dan informatif sehingga dapat meningkatkan lagi penanganan dan dapat menjadi acuan penelitian lanjut.

Untuk peneliti selanjutnya diharapkan agar mencari sampel lebih banyak serta meneliti lebih lanjut tentang infeksi akibat penggunaan ventilator.

\section{DAFTAR PUSTAKA}

1. Singer M, Deutchman C, Seymour WC, Manu Shankar-Hari, Djillali Annane D, Bellomo R, et al. The Third International Consensus Defini-tions for sepsis and septic shock (Sepsis-3). JAMA. 2016;315(8):804-6. 
2. Honore PM, Jacobs R, Joannes-Boyau O, De Regt J, Boer W, De Waele E, et al. Septic AKI in ICU patients, diagnosis, pathophysiology and treatment type, dosing, and timing: a comprehensive review of recent and future develop-ments. Ann Intensive Care. 2011;1:32.

3. Barsten A, Soni N. Oh's Intensive Care Manual (6 ed). China: Butterworth Heinemann Elsevier, 2009.

4. Kumar A, Zarychanski R, Light B, Parrillo J, Maki D, Simon D, et al. Early combination antibiotic therapy yields improved survival compared with monotherapy in septic shock: A propensity-matched analysis. Crit Care. 2010;38(9):1776.

5. Sejati A, Pitoyo CW, Suhendro, Abdullah M. Faktor-faktor prognostik mortalitas pasien sepsis berat fase lanjut di Unit Perawatan Intensif Rumah Sakit Cipto Mangunkusumo Jakarta. Jakarta: FKUI/RSCM. Available from: www.indonesia journalchest.com/.../Faktor-Faktor\%20 Prognostik\%...

6. Tambajong RN, Lalenoh DC, Kumaat L. Profil penderita sepsis di ICU RSUP Prof. Dr. R. D. Kandou Manado periode Desember 2014-November 2015. e-Cl. 2016;4:456.

7. Rahmawati MA. Angka kejadian pneumonia pada pasien sepsis di ICU RSUP Dr Kariadi Semarang [Karya Tulis Ilmiah Jurnal Medika Muda]. Semarang:
Universitas Diponegoro; 2014.

8. Koenig SM, Truwit JD. Ventilator associated pneumonia: Diagnosis, treatment and prevention. [cited 2014 July 10]. Available from: www.ncbi. nlm.nih.gov/pmc/articles/PMC1592694 $17 /$

9. Hackethal V. Risk for death decreased in icu patients with severe sepsis. 2014. [cited 2014 July 10]. Available from: http://www.medscape.com/viewarticle/ 822176

10. Dahlan Z. Ilmu Penyakit Dalam (6th ed). Jakarta: Balai Penerbit FKUI, 2014.

11. Dick A, Liu H, Zwanzinger J, Perencevich E, Furuya EY, Larson E, et al. Longterm survival and healthcare ultilization outcomes atributable to sepsis and pneumonia. BMC Health Serv Res. 2012;12:432.

12. Dreger NM, Degener S, Ahmad-Nejad P, Wöbker G, Roth S. UrosepsisEtiology, Diagnosis, and Treatment. Dtsch Arztebl Int. 2015;112:837.

13. Basuki P. Dasar-dasar Urologi (2nd ed). Jakarta: Sagung Seto, 2008; p. 51.

14. Nurman A. Kolangitis akut yang dipandang dari sudut penyakit dalam. J Kedokter Trisakti. 1999;18:124.

15. Patra RH, Semedi BP. Hubungan antara ketaatan penerapan sepsis resuscita-tion bundle pada pasien sepsis dengan hasil terapi yang diukur dengan parameter mikrosirkulasi laktat serum. Journal of Emergency. 2011;1:3. 